\title{
Growth of white lupin seedlings during the rosette stage as affected by seed size
}

\author{
C Huyghe \\ INRA, Station d'Amélioration des Plantes Fourragères, 86600 Lusignan, France
}

(Received 26 June 1992; accepted 7 December 1992)

\begin{abstract}
Summary - Mean seed weight has a major influence on the early growth of seedlings in numerous species. In white lupin (Lupinus albus $L$ ), it affected organogenesis and growth during the rosette stage. An increase in mean seed weight induced a non-linear increase in the number of leaf primordia produced by the main apex at the vegetative stage. The relationship between the mean seed weight and the number of leaf primordia was similar whatever the genotypic or phenotypic origin of the seed size variation. The sums of temperatures from sowing had a curvilinear effect on the number of leaf primordia. A general multiplicative model was developed. The dry weight of the cotyledons remained constant after their full expansion. The dry weights of the leaf and root parts of the seedlings during the rosette stage were positively and almost linearly linked to the mean seed weight, thermal time had an exponential effect on the dry weight of the leaf and root parts of the lupin seedlings. General models for these characters were developed. Temperature appeared as the major environmental factor affecting the growth at the early stages. The consequences of these relationships for the development of a general morphogenetic model for seed multiplication programs and breeding objectives are discussed.
\end{abstract}

Lupinus albus L / white lupin / seed size / leaf primordia / early growth / thermal time

Résumé - Effet de la taille des graines semées sur la croissance des plantules de lupin blanc durant le stade rosette. La taille de la graine semée a une influence majeure sur la croissance précoce des plantules chez de nombreuses espèces. Chez le lupin blanc (Lupinus albus L), ce caractère affecte à la fois l'organogénèse et la croissance. Une augmentation du poids du grain semé conduit à une augmentation non linéaire du nombre de primordiums émis par l'apex principal au stade végétatif après un temps de croissance donné. Cette relation entre la taille de la graine et le nombre de primordiums foliaires émis est similaire, que la taille de la graine ait une origine génotypique ou phénotypique. Les sommes de températures reçues depuis le semis ont un effet curvilinéaire sur le nombre de primordiums émis. Un modèle multiplicatif général permettant la prédiction du nombre de primordiums foliaires (y) selon les sommes de températures depuis le semis $(x)$ et la taille du grain semé $(z)$ a été développé : $y=(5,25+0,042+$ $\left.0,00000942 x^{2}\right) z^{0,12}$. Le poids sec des cotylédons reste constant après la fin de leur expansion. Les poids secs des parties aériennes et racinaires au long du stade rosette sont positivement et presque linéairement liés au poids du grain semé, les sommes de températures depuis le semis ayant un effet exponentiel sur les poids secs des parties aériennes et racinaires. Des modèles généraux pour la croissance de ces compartiments ont été établis. La température apparaît comme le principal facteur environnemental affectant la croissance aux stades précoces. Les conséquences de ces relations sur le développement de modèles morphogénétiques généraux, sur les programmes de multiplication des semences et sur les objectifs de sélection, sont discutées.

Lupinus albus L / lupin blanc / taille du grain / primordiums foliaires / croissance précoce / somme de températures 


\section{INTRODUCTION}

Mean seed weight is an important factor of stand establishment. The relationship between seed weight and germination is not constant. In various species, a positive correlation was found: the heavier seeds showing a higher germination percentage as shown in Vigna mungo and Vigna radiata (Chandra Babu et al, 1990) or in lentil (Waldia et al, 1990). In these cases, there could be a certain percentage of unviable or abnormal seeds among the small seeds. In other experiments, no relationship was reported. It is likely that in these cases, the history of the seeds on the mother plant, for instance the environmental conditions during their ripening, had a major influence on the germination as shown in soybean (Mugnisjah and Nakamura, 1986).

On the contrary, the effect of seed weight on growth is very constant. Within a species, a large seed size induces the production of more vigorous seedlings with heavier fresh and dry weight. This feature has been reported in many species: legumes: Desmodium paniculatum (Wulff, 1986), Vigna radiata and Vigna mungo (Chandra Babu et al, 1990), Trifolium subterraneum (Black, 1957), Lens culinaris (Waldia et al, 1990); other annual species: Hordeum (Giles, 1990), Zea mays (Pommel, 1990), Sorghum (Wenzel, 1990), Brassica oleracea (Shanmuganathan and Benjamin, 1992) and in trees: Pinus caribaea (Toon et al, 1991). The heavier seedling weight was atways linked with larger organs, increased leaf area, taller seedlings and often with an increased growth rate. No effect on organogenesis has been reported whatever the species.

The larger seeds also allow a better tolerance to unfavorable conditions during early growth. This was shown by Heather and Sieczka (1991) for the establishment of broccoli (Brassica oleracea spp italica) in crusted soils. In Hordeum vulgare ssp spontaneum, Giles (1990) showed that the positive effect of the seed size on the seedling growth and weight was due to the amount of nutrient reserves available for early growth. This improved crop establishment is of a great interest for the crops which have to experience severe conditions during the early growth as the autumn or winter-sown crops.

Autumn-sown white lupin is characterized by a long rosette stage during which the plant produces leaves without elongation of the corresponding internodes. The rosette stage ends when the main apex becomes floral, which depends on the vernalizing conditions and the vernalization requirements of the genotype under cultivation. The duration of this stage and the growth of the seedlings during this stage play a critical role for the frost tolerance of the seedlings via the size of the root parenchyma and the vegetative or floral stage of the main apex (Huyghe and Papineau, 1990). This period also has significant consequences on the structure of the resulting plants because organogenesis of the main apex occurs during the rosette stage. The final number of leaves on the main stem results from the rate of leaf primordia production and from the time when vernalization occurs, ie when the apex becomes floral. This has been modelled on the cultivar Lunoble (Huyghe, 1991). It has been shown in this late flowering winter cultivar that the number of leaf primordia produced by a main apex at the vegetative stage is a curvilinear function of the sums of temperatures $>3^{\circ} \mathrm{C}$ at sowing.

In order to develop a model operating on a range of genotypes, it is important to estimate the genetic variability available for leaf primordia production and vernalization requirements. The present paper will focus on the rosette stage, period of leaf primordia production, and assess the possible phenotypic and genotypic sources of variation for organogenesis and growth of the seedlings during this stage. Seed size has been reported as one of the major sources of variation for the growth in many species but no effect on leaf primordia production has been reported in the literature. Mean seed weight is a highly heritable character which shows a wide variation among white lupin genetic resources from 0.150 $\mathrm{g}$ (Ramos Monreal and Aragon, 1984) to $1 \mathrm{~g}$ per seed (Papineau, 1987). As it is a major yield component, it is of major interest to measure its influence on the early development of the lupin plants.

This paper presents results of field experiments conducted to assess and model the effect of seed size and genotype on the organogenesis of the main stem, ie leaf primordia initiation of winter type white lupin and on seedling growth during the rosette stage. These experiments were conducted either in autumn or in spring in order to obtain different temperature and radiation conditions.

\section{MATERIAL AND METHODS}

A set of 29 genotypes was considered in this study, which comprised 3 experiments (table I). 
Table I. Plant material involved in the 3 experiments.

Genotype

Mean seed weight ( $g /$ seed)

Experiment 1: Sowing date: 21/9/1990

$\begin{array}{ll}\text { Lunoble (1) } & 0.148 \\ \text { Lunoble (2) } & 0.195 \\ \text { Lunoble (3) } & 0.243 \\ \text { Lunoble (4) } & 0.292 \\ \text { Lunoble (5) } & 0.351 \\ \text { ITA32 } & 0.192 \\ \text { C164 } & 0 ., 241 \\ \text { ITA28 } & 0.289 \\ \text { ITA41 } & 0.337 \\ \text { ITA56 } & 0.384 \\ \text { ITA10 } & 0.435 \\ \text { ITA13 } & 0.484 \\ \text { ITA53 } & 0.533 \\ \text { ITA26-1 } & 0.586 \\ \text { ITA26-2 } & 0.700\end{array}$

Experiment 2: Sowing date: 19/2/1990

$\begin{array}{ll}\text { C80 } & 0.222 \\ \text { LA99 } & 0.249 \\ \text { ITA29 } & 0.301 \\ \text { ITA41 } & 0.356 \\ \text { ITA60 } & 0.355 \\ \text { ITA9 } & 0.376 \\ \text { LA109 } & 0.406 \\ \text { ITA56 } & 0.458 \\ \text { ITA23 } & 0.504 \\ \text { ITA26 (1) } & 0.613 \\ \text { ITA26 (2) } & 0.662 \\ \text { Lunoble (6) } & 0.200 \\ \text { Lunoble (7) } & 0.250 \\ \text { Lunoble (8) } & 0.297\end{array}$

Experiment 3: Sowing date: 18-9-1991

$\begin{array}{ll}\text { Lumineux } & 0.216 \\ \text { Lunoble } & 0.235 \\ \text { XA100 } & 0.322 \\ \text { Adam (1) } & 0.298 \\ \text { Adam (2) } & 0.244 \\ \text { Alex } & 0.333 \\ \text { CH304-71 } & 0.283 \\ \text { VH304-73 } & 0.197 \\ \text { CH46 } & 0.419 \\ \text { Ac62 } & 0.376 \\ \text { Ac12 } & 0.376 \\ \text { Ac93 } & 0.415 \\ \text { Ac163 } & 0.494 \\ \text { Ac127 } & 0.556\end{array}$

The genotypes were of 3 types: i) cultivars: Adam (Caussade Semences), Alex (GIE Lupsem), Lumineux (INRA), Lunoble (INRA); ii) genotypes under selection: $X A 100$, genotypes identified by codes beginning by $C$ or $\mathrm{CH}$; or iii) populations received through exchanges
(LA) or collected in Italy (ITA) or the Azores (Ac). The cultivar Lunoble was studied in the 3 experiments. In the first 2 experiments, different seed batches of this cultivar with different mean seed weight were constituted and used to test the intra-genotypic validity of the models.

All the seeds were dried at room temperature till equilibrium. Their water content was then $\approx 10 \%$. The seeds were individually weighed and the seeds whose individual mass was $\pm 10 \mathrm{mg}$ of the desired mean seed weight were used in the experiments.

The seed batches, ie the genotypes and their mean seed weight (MSW), and the sowing time of the 3 experiments are given in table $I$.

The seedlings were grown at 14 plants $/ \mathrm{m}^{2}$ with $10 \mathrm{~cm}$ between plants per row and with rows $0.7 \mathrm{~m}$ apart. This low density, which is in the range of density optimum for the autumn-sown white lupin (Huyghe, 1990) allowed a growth of the seedlings with negligible competition.

In experiment 1,3 replicates of 6 seedlings were collected after 240,480 and $620^{\circ} \mathrm{C}$.d from sowing. On each seedling, the number of leaf primordia of the main stem apex was recorded.

In experiment 2,3 replicates of 6 seedlings were collected after $120,190,250,340$ and $410^{\circ} \mathrm{C} . \mathrm{d}$ from sowing. The number of leaf primordia on the main apex of each seedling was recorded. From the third sampling onwards, the leaves and the roots plus cotyledons from each replicate, were dried at $80{ }^{\circ} \mathrm{C}$ for $48 \mathrm{~h}$ and weighed. The dry weight of the roots alone was calculated by subtracting from the roots plus cotyledon weight the weight of the cotyledons estimated by the relationship developed with the data in experiment 3 .

In experiment 3, 3 replicates of 5 seedlings were collected after 110, 170, 240, 305, 360, 456, 516, 575 and $660^{\circ} \mathrm{C} . \mathrm{d}$ from sowing. In the first 8 samplings, the number of leaf primordia of the main apex was recorded on each seedling. From the third to the ninth sampling, the dry weights of the roots (RDM), the cotyledons (CDM) and the leaves (LDM) were measured on each replicate after the organs had been dried at $80^{\circ} \mathrm{C}$ for $48 \mathrm{~h}$.

In the 3 experiments, the number of leaf primordia was recorded only when the apex was at the vegetative stage and hence this character was not recorded at the last sampling of experiment 3 because the early genotypes were in the floral stage.

The soil for the 3 experiments was a deep clay silt (pH 6.7) with an available soil water content at field capacity of $100 \mathrm{~mm}$. Before sowing, the soil was sprayed with $1.5 \mathrm{~kg} \mathrm{ma} / \mathrm{ha}$ of chlorpyriphos-ethyl and $0.790 \mathrm{~kg} \mathrm{ma} / \mathrm{ha}$ of lindane to control bean fly (Phorbia platura) infection. A post-sowing - pre-emergence herbicide was used for weed control.

The weather conditions during the 3 experiments are given in table II.

The sums of temperature from sowing, in degreedays, were calculated with $3{ }^{\circ} \mathrm{C}$ as the threshold temperature according to the method developed by Huyghe (1991). 
Table II. Decade means for maximum $\left({ }^{\circ} \mathrm{C}_{\max }\right)$ and minimum $\left({ }^{\circ} \mathrm{C}_{\min }\right)$ temperature, and decade total rainfall for the 3 experiments.

Experiment $1(21 / 9 / 1990)$

\begin{tabular}{lrrrlrrrr} 
& \multicolumn{3}{c}{ September } & \multicolumn{3}{c}{ October } & \multicolumn{3}{c}{ November } \\
& $11-20$ & $21-30$ & $1-10$ & $11-20$ & $21-31$ & $1-10$ & $11-20$ & $21-30$ \\
& & & & & & & & \\
${ }^{\circ} \mathrm{C}_{\max }$ & 24.0 & 20.7 & 18.7 & 20.6 & 15.5 & 11.9 & 13.4 & 7.0 \\
${ }^{\circ} \mathrm{C}_{\min }$ & 11.3 & 10.4 & 8.0 & 11.5 & 9.1 & 4.1 & 9.5 & 1.9 \\
${ }_{\text {Rain }}(\mathrm{mm})$ & 4.0 & 24.0 & 3.5 & 33.0 & 107 & 18.0 & 37.5 & 31.0
\end{tabular}

Experiment 2(19/2/1991)

\begin{tabular}{llllllll} 
& February & \multicolumn{9}{c}{ March } & & & April \\
& $19-28$ & $1-10$ & $11-20$ & $21-30$ & $1-10$ & $11-20$ & $21-31$ \\
${ }^{\circ} \mathrm{C}_{\max }$ & 13.1 & 14.1 & 15.0 & 11.0 & 13.6 & 17.6 & 12.4 \\
${ }^{\circ} \mathrm{C}_{\min }$ & 2.2 & 6.2 & 7.7 & 4.9 & 3.8 & 5.8 & 1.6 \\
Rain $(\mathrm{mm})$ & 3.5 & 17.5 & 22.0 & 37.5 & 15.0 & 1.5 & 10.0
\end{tabular}

Experiment $3(18 / 9 / 1991)$

\begin{tabular}{lllllllllll} 
& \multicolumn{3}{c}{ September } & \multicolumn{3}{c}{ October } & \multicolumn{3}{c}{ November } & \multicolumn{2}{c}{ December } \\
& $11-20$ & $21-30$ & $1-10$ & $11-20$ & $21-31$ & $1-10$ & $11-20$ & $21-30$ & $1-10$ & $11-20$ \\
${ }^{\circ} \mathrm{C}_{\max }$ & 25.6 & 19.9 & 18.3 & 14.5 & 12.9 & 13.3 & 11.3 & 9.1 & 4.8 & 8.7 \\
${ }^{\circ} \mathrm{C}_{\min }$ & 13.7 & 12.3 & 7.5 & 9.2 & 5.8 & 7.6 & 4.7 & 1.2 & 0.1 & 1.3 \\
Rain (mm) & 18.5 & 55.0 & 9.5 & 22.0 & 33.0 & 33.5 & 73.0 & 6.0 & 0.0 & 5.0 \\
\hline
\end{tabular}

The computer software SAS (Statistical Analysis System) was adopted for all calculations.

\section{RESULTS}

\section{Effect of genotype and mean seed weight on the number of leaf primordia}

\section{Genotypic effect}

Experiment 2 had 11 genotypes, Lunoble and ITA26 being represented by 3 and 2 seed batches respectively and 5 sampling dates. An analysis of variance with 2 factors, sampling dates and genotype, showed a prevalent effect of the sampling date, $91 \%$ of the sums of squares, the genotypic effect also being highly significant with $2.69 \%$ of the sums of squares. However, there was a significant correlation between the genotypic mean of the number of leaf primordia and the genotypic mean seed weight $(r=0.92$ for $9 \mathrm{ddl})$.
This relationship is clearly illustrated in figure $1 \mathrm{~b}$ which shows the effect of the mean seed weight on the number of leaf primordia after $340^{\circ} \mathrm{C}$.d in experiment 2. Figure 1a shows the same relationship for the second sampling of experiment 1. As can be seen in figure 1, there was a variation between the different seed batches of Lunoble in both experiments, this variation being associated with variation of the mean seed weight. The relationship between the number of leaf primordia and the mean seed weight was curvilinear.

\section{Definition and validation of a general model}

Experiment 3, in which the involved genotypes were different from those of the first 2 experiments except for 1 Lunoble seed batch was used to define a general model which would determine the number of leaf primordia of a vegetative apex in terms of the sum of temperatures from sowing and the mean weight of the seed.

Using the mean of the 3 replicates for the 14 seed batches and the 8 first samplings, different 

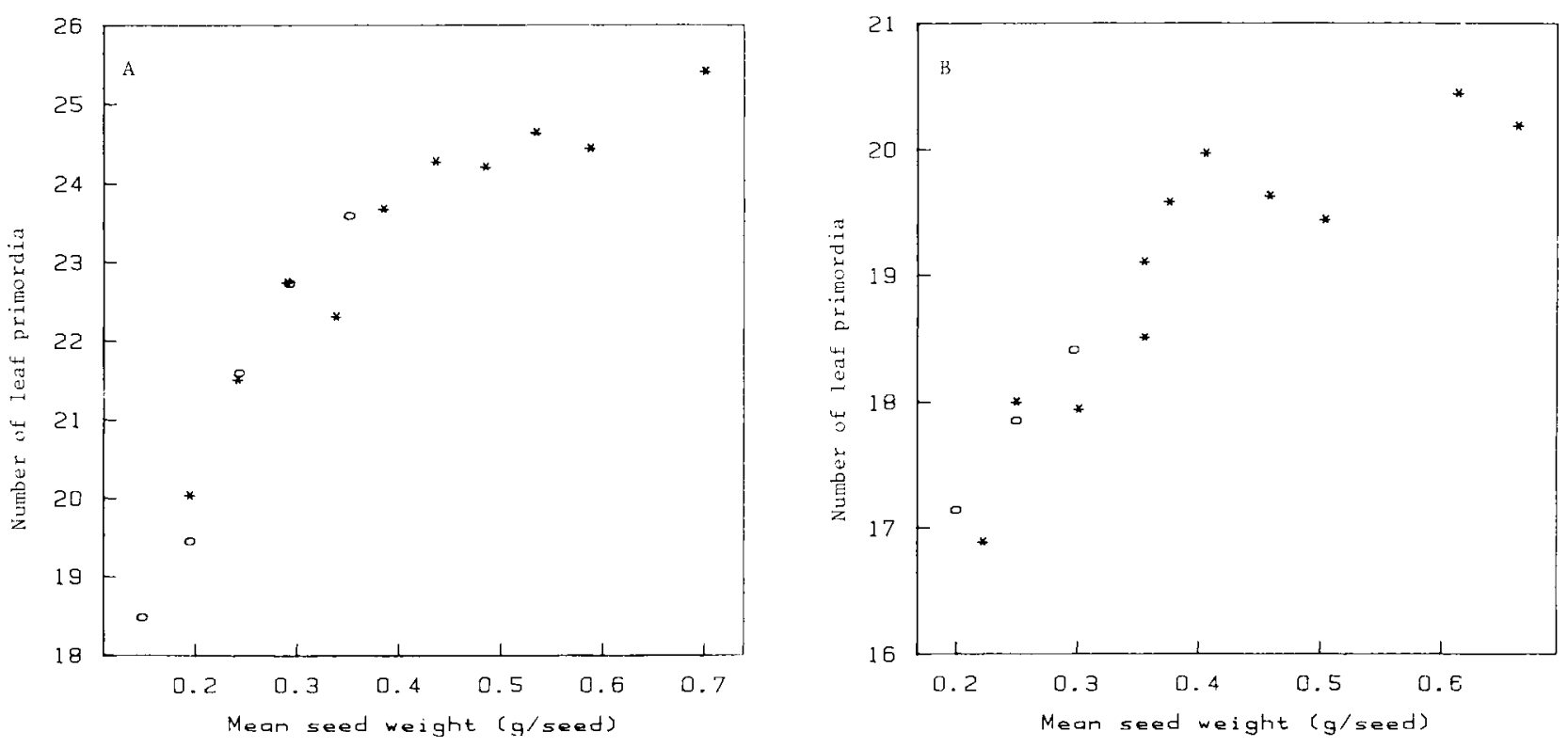

Fig 1. Effect of the mean seed weight $(\mathrm{g} / \mathrm{seed})$ on the number of leaf primordia produced by the main apex during the vegetative stage after $480^{\circ} \mathrm{C}$.d from sowing in experiment 1 (A) and $340^{\circ} \mathrm{C}$.d in experiment 2 (B). The symbol $\mathrm{O}$ represents the different seed batches of the cultivar Lunoble while * represents the intergenotypic variation.

types of model were tested for the percentage of the mean square explained by the model.

Linear and curvilinear regressions were tested for the effect of the sums of temperature and the quadratic regression proved to be the best one, as observed by Huyghe (1991) in the cultivar Lunoble alone.

Among the different models tested for the effect of the mean seed weight, the best fitting type of $\epsilon_{y}$ uation was:

$$
y=a x^{b}
$$

A general multiplicative model was determined:

$$
y=\left(5.25+0.042 x+0.00000942 x^{2}\right) z^{0.12}
$$

with $y$ : the number of leaf primordia, $x$. the sum of temperatures from sowing $\left({ }^{\circ} \mathrm{C} . d\right)$ and $z$ : the mean seed weight ( $\mathrm{g} / \mathrm{seed}$ ).

$R^{2}$ was 0.989 with 107 degrees of freedom. The asymptotic $95 \%$ confidence intervals of the 4 parameters of the equation are presented in table III. There was no correlation between the parameters accounting for the effect of the sums of temperatures since sowing, ie $A_{0}, A_{1}$ and $A_{2}$ and $B_{0}$ representing the effect of the mean seed weight. Figure 2 shows the effect of the sum of
Table III. Estimate and confidence intervals of the parameters of the general model describing the leaf primordia production $y=\left(A_{0}+A_{1} x+A_{2} x^{2}\right) z^{B 0}$ with $x$ being the sum of temperatures from sowing and $z$ the mean seed weight.

Estimate Asymptotic 95\% confidence interval

\begin{tabular}{lll}
\hline & Lower & Upper \\
& & \\
\hline & 4.47 & 6.03 \\
0.037 & 0.047 \\
-6 & $2.110^{-6}$ & $1.610^{-5}$ \\
& 0.10 & 0.14
\end{tabular}

temperatures $>3^{\circ} \mathrm{C}$ from sowing on the number of leaf primordia for the genotype Ac163, the predicted value and the confidence intervals of an individual prediction of a sample of 15 plants.

The general equation of the model was validated using the data of the first 2 experiments as a verification set. The plant material of these experiments was different from that involved in the third experiment, apart from 1 seed set of cultivar Lunoble.

The correlation between the predicted and the observed number of leaf primordia on the main 


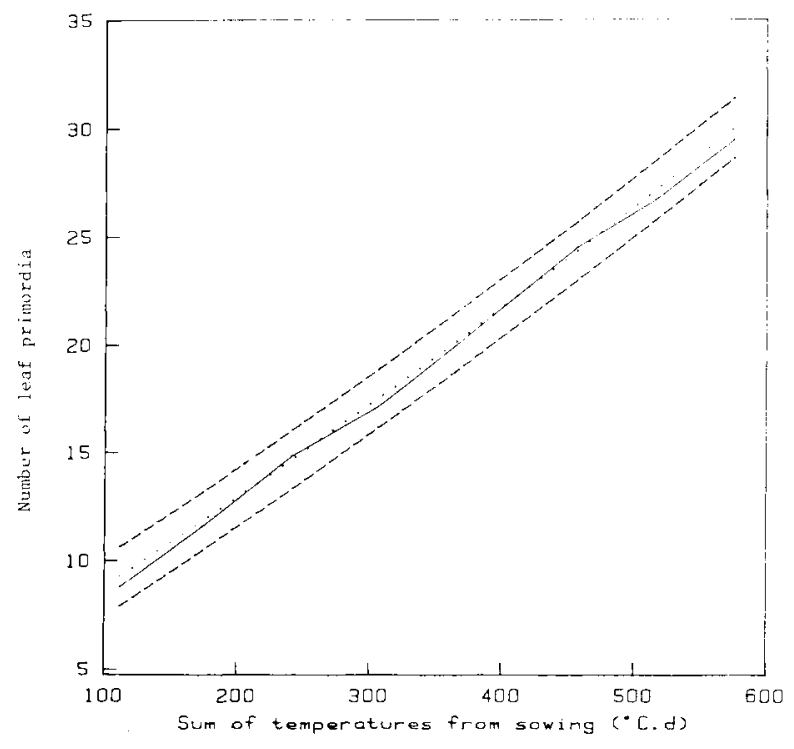

Fig 2. Effect of the sums of temperatures from sowing on the number of leaf primordia produced by the main apex of Ac163 (---). The dotted line (....) represents the predicted value and the broken line (----) the confidence intervals for an individual prediction of a 15-plant sample.

apex was 0.98 with $113 \mathrm{df}$. The equation for the regression was then:

$$
y=0.57+0.97 x
$$

with $y$ being the observed and $x$ the predicted leaf primordia numbers.

The slope was not significantly different from 1 while the intercept was not significantly different from 0.

This verification set could be divided in 2 subsets. The first included the different seed lots of the cultivar Lunoble in which a wide range of seed weight had been sorted out, this subset allowed to the intra-genotypic validity of the model be checked. The other one included the seed lots of different genotypes for verification of the inter-genotypic validity of the model.

The correlation coefficients for these 2 subsets were 0.977 and 0.987 respectively with equations of regression similar to the overall regression.

\section{Genotypic effect independant of the seed size}

After correction by the mean seed weight effect, the number of leaf primordia being divided by (mean seed weight) ${ }^{0.12}$, a variance analysis was performed. There was still a genotypic effect but which accounted for only $0.3 \%$ of the sum of squares.

Although significant, this genotypic effect independent of seed size was very small and the general model is therefore satisfactory for describing the leaf primordia production by the main apex during its vegetative stage for different seed batches whatever the mean seed weight and whatever the phenotypic or genotypic origin of the seed size. The validity area of the model ranges from $0-600{ }^{\circ} \mathrm{C} . \mathrm{d}$ for the sums of temperatures and from $0.2-0.6 \mathrm{~g}$ for the mean seed weight.

\section{Effect of mean seed weight on seedling growth}

Using the samplings from which seedling growth data had been collected, ie the 3 last samplings of experiment 2 and the 7 last samplings of experiment 3 , the effects of thermal time from sowing and of mean seed weight of the planted seed on growth of the different compartments of the seedlings were analysed.

On the data of the third experiment, analysis of variance showed a significant effect of the date of sampling and of genotype on the dry weight of the leaves and of the roots. The dry weight of the cotyledons was only influenced by the genotype but was independent of thermal time from sowing after the third sampling, ie $240^{\circ} \mathrm{C}$.d from sowing. The genotypic effects calculated for these 3 characters were highly correlated with the mean seed weight of the planted seed.

The relationships between dry weight of the different compartments, sums of temperature from sowing and mean seed weight were described by equations.

\section{Cotyledon weight}

During the period of time considered in experiment 3 , ie between $240-660^{\circ} \mathrm{C}$.d from sowing, the dry weight of the cotyledons was stable and depended only on the mean seed weight. $240^{\circ} \mathrm{C} . \mathrm{d}$ is the thermal time necessary for the seedlings to emerge and reach the full expansion of the cotyledons, emergence taking place after $150{ }^{\circ} \mathrm{C} . \mathrm{d}$. The dry weight of the cotyledons was calculated as the average over the different sam- 
plings of experiment 3 . The relationship between this mean cotyledon weight per seedling and the mean seed weight was established from experiment 3:

$$
C D M=-0.003+0.2625 z \quad R^{2}=0.970(12 \mathrm{df})
$$

where $C D M$ is the dry weight of the 2 cotyledons of a seedling and $z$ the mean seed weight of the planted seed.

\section{Aerial growth}

The seed weight, as illustrated in figure $3 a$, had a strong effect on the dry weight of the aerial part of the seedlings. The thermal time also had a strong influence on the growth of the aerial part (fig 3b).

A general model between the dry weight of the aerial part, the thermal time and the mean seed weight can be proposed:

$$
L D M=0.115 \exp (0.0054 x) \quad z^{0.895} \quad R^{2}=0.973
$$
(138 df)

with LDM: dry weight of the aerial part $(\mathrm{g} /$ seedling), $x$ : thermal time from sowing over $3{ }^{\circ} \mathrm{C}$ $\left({ }^{\circ} \mathrm{C} . \mathrm{d}\right)$ and $z$ : mean seed weight $(\mathrm{g} / \mathrm{seed})$.

\section{Root growth}

The dry weights of the roots for experiment 2 were calculated using the equation describing the

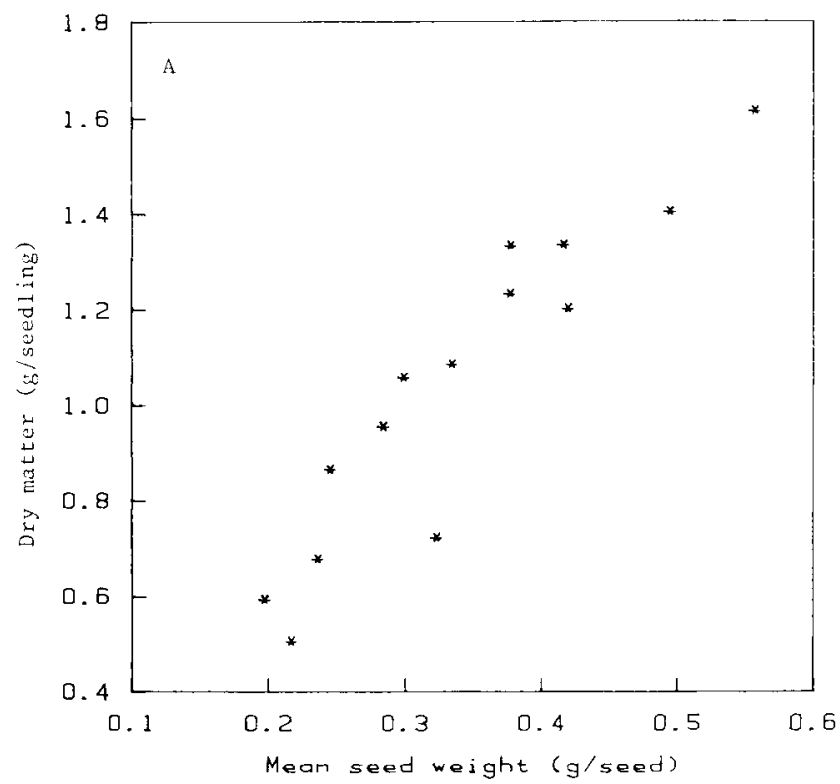

relationship between the cotyledon dry weight and the mean seed weight.

Analysis of root growth over experiments 2 and 3 showed effects of thermal time and mean seed weight to be very similar to those observed on the aerial parts. A similar general model was developed:

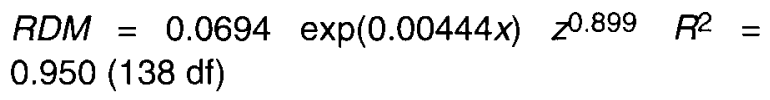

with RDM: dry matter of the roots ( $\mathrm{g} /$ seedling), the value of $x, z$ being similar to that in the previous paragraph.

\section{DISCUSSION}

This paper presents the consequences of seed size on the early growth of the winter type white lupin. Due to high vernalization requirements, this lupin type is characterized by a long rosette stage during which the vegetative apex produces leaf primordia and the corresponding internodes do not elongate.

During this period, the mean seed weight has a major influence on organogenesis and on the growth of the seedlings.

\section{Organogenesis}

The mean seed weight had a non-linear effect on the number of leaf primordia. The type of re-

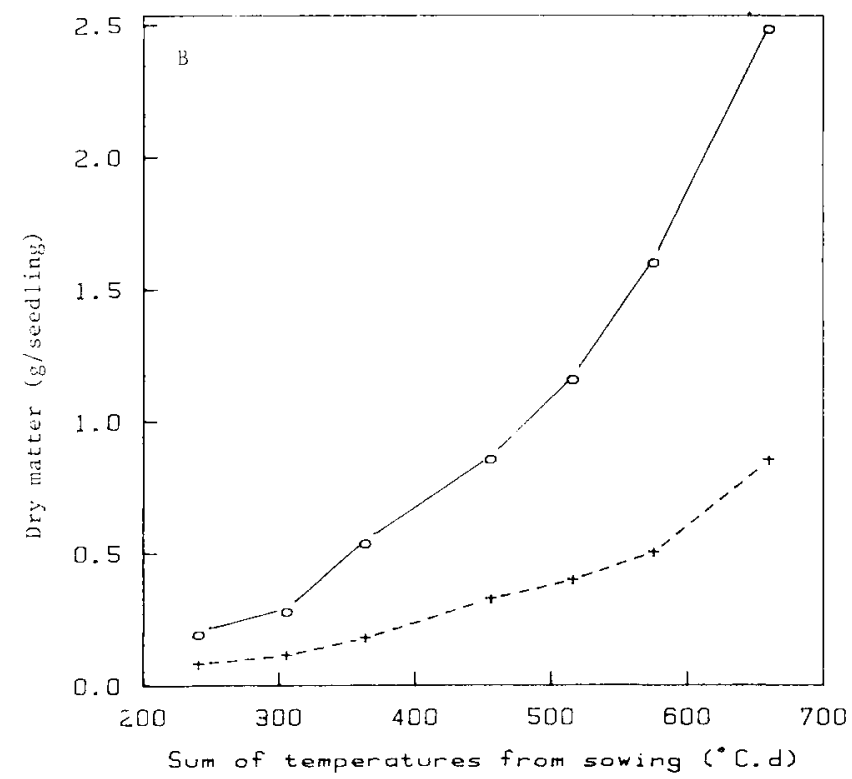

Fig 3. Effect of the mean seed weight after $575^{\circ} \mathrm{C}$.d from sowing (A) and the sums of temperatures from sowing (B) on the dry weight of the aerial parts ( $\mathrm{g} / \mathrm{seedling}$ ). The graph B shows the growth of the genotype Ac127 (--0--) with a mean seed weight of 0.55 $\mathrm{g}$ and of the cultivar Lumineux (----) with a mean seed weight of $0.21 \mathrm{~g}$. 
gression suggests a complex relationship which could be an allometric effect of the mean seed weight on the size of the main apex and consequently on its mitotic activity as suggested by Sunderland and Brown (1976). This would eventually result in a modification of primordia production rate. The general equation with a high $R^{2}$ for both the intra-genotypic and the intergenotypic seed size variation will allow the satisfactory prediction of the number of leaf primordia for any seed batch whatever the genotype and the origin of the seed at any time during the vegetative stage of the main apex. This will be of great interest for the development of general models for the structure of the main stem of genotypes with very different seed sizes.

The genotypic residuals to the general model, while significant, were very small with regard to the overall variation and could be due to different efficiency of the seed reserve as has been reported for the production of dry matter in sorghum seedlings (Wenzel, 1990). Similarly, in the present study, the possible origin of the genotypic effect independent of the seed size could be the cotyledon dry weight used. Indeed, in experiment 3 , the genotypic effect independent of the seed weight was calculated. A cotyledon dry weight use has also been calculated. The water content of all the seed batches being the same $(\Phi)$, approximately $10 \%$, and assuming that the proportion (k) of seed weight present in the cotyledons was constant whatever the seed weight $(w)$, approximately $82 \%$, it was possible to calculate cotyledon dry weight use (r) as:

$$
r=1-C D M / C
$$

with $c$ the cotyledon dry weight in the seed $=w^{*}$

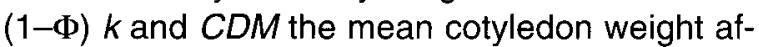
ter their full expansion.

$r$ was in fact close to the residuals to the regression between the mean seed weight and the cotyledon dry weight.

The correlation between the genotypic effect independent of the seed weight and the genotypic cotyledon dry weight use was 0.508 for $11 \mathrm{ddl}$. Although not significant, this correlation suggested that a higher utilisation of the cotyledon reserve could allow a quicker leaf primordia production.

\section{Growth}

The exponential effect of thermal time on aerial part dry weight is the consequence of the fact that, at such early stages during the rosette stage, the aerial part is composed only of leaves, ie of a photosynthetically active area, and there is no competition between plants. The sums of temperatures were involved in the prediction models of the dry matter accumulation because, at these early stages and at the seasons when these experiments took place, temperature was the factor controlling leaf area development. Consequently, the growth of the leaf compartment results in an increase of the leaf area per plant and of the subsequent photosynthesis. Such features have been reported in many species (Rooney et al, 1989; Calouin et al, 1990) and are examples of the leaf dry weight of the general approach of the responses of plant processes to temperature proposed by Johnson and Thornley (1985).

The almost linear increase due to mean seed weight during all the rosette stage can be explained by an early difference, just after emergence, in leaf area per plant when the leaf area was very limited. This slight difference then increased with the thermal time. This underlines the impact of the seed quality on the early growth of the lupin seedlings.

The seed size has a genotypic origin and a phenotypic origin. The genotypic effect on the seed size stresses out the consequences of options taken by the breeders in terms of optimum seed size especially the reduction of the mean seed weight for reducing the seed cost.

The phenotypic variations are the variations observed for a given genotype in various environments. They originate either from an intra-canopy variation, ie the seed size variation within a plant which is the consequence of the differences between pod levels and of the variation within an inflorescence as reported in Lupinus texensis (Schaal, 1980) or as a consequence of the site, husbandry or weather conditions (Julier et al, 1993). The use of small seed could result in a poor winter growth of the crop and a poor crop establishment, increase the risks of damage during the winter and consequently endanger the crop.

The almost linear effect of the mean seed weight on the aerial part of the seedlings will stop when the canopy will be complete as it has been shown by Black (1957) on subterranean clover. However, the interception of incident light energy will be maximum earlier with the large-seeded genotypes allowing a better light interception and a higher accumulation of dry matter at the early stages of the crop. For uncrowded plants, this ef- 
fect of seed size would disappear with the changes in the plant stage, with different assimilates partitioning. This is visible when a reproductive sink has been established as observed after flowering in marigolds (Weiner et al, 1990).

\section{REFERENCES}

Black JN (1957) Seed size as a factor in the growth of subterranean clover (Trifolium subterraneum $\mathrm{L}$ ) under spaced and sward conditions. Austr J Agric Res $8,335-351$

Calouin C, Clement B, Herrmann S (1990) Regrowth kinetics of Dactylis glomerata following defoliation. Ann Bot 66, 397-405

Chandra Babu R, Muralidharan V, Seetha Rani M, Nagarajan M, Sree Rangasamy SR, Pallikonda Perumal RK (1990) Effect of seed size on germination and seedling growth in greengram (Vigna radiata $\mathrm{L}$ Wilczek) and blackgram (Vigna mungo L Hepper) cultivars. J Agron Crop Sci 164, 213-216

Giles BE (1990) The effects of variation in seed size on growth and reproduction in the wild barley Hordeum vulgare ssp spontaneum. Heredity 64, 239-250

Heather DW, Sieczka JB (1991) Effect of seed size and cultivar on emergence and stand establishment of broccoli in crusted soil. J Am Soc Hortic Sci 116, 946-949

Huyghe C (1990) White lupin architecture - genetic variability - agronomic consequences. In: Proc 6th Int Lupin Conf. Temuco, Chile, 25-30 Nov 1990, 241-254

Huyghe C (1991) Winter growth of autumn-sown white lupin (Lupinus albus $\mathrm{L}$ ): main apex growth model. Ann Bot 67, 429-434

Huyghe C, Papineau J (1990) Winter development of autumn-sown white lupin: Agronomic and breeding consequences. Agronomie 10, 709-716

Johnson IR, Thornley JHM (1985) Temperature dependence of plant and crop processes. Ann Bot 55, 1-24

Julier B, Huyghe C, Papineau J, Milford GFJ, Day JM, Billot C, Mangin P (1993) Yield and yield stability of determinate and indeterminate autumn-sown white lupins (Lupinus albus $\mathrm{L}$ ) at different locations in France and the UK. J Agric Sci (in press)
Mugnisjah WQ, Nakamura S (1986) Vigour of soybean seed as influenced by sowing and harvest dates and seed size. Seed Sci Technol 14, 87-94

Papineau J (1987) La résistance au froid des lupins blancs (Lupinus albus $\mathrm{L}$ ). Variabilité génétique, sélection, création de matériel végétal doux. Mém Ingénieur DPE, ENSA Montpellier, 1987, $67 \mathrm{p}$

Pommel B (1990) Influence du poids de la semence et de la profondeur du semis sur la croissance et le développement de la plantule de maïs. Agronomie 10, 699-708

Ramos Monreal A, Aragon AG (1984) Recursos geneticos del altramuz en la Peninsula Iberica. In: Proc 3rd Int Lupin Conf. La Rochelle, France, 4-8 June 1984, 110-158

Rooney JM, Brain P, Yin Loh S (1989) The influence of temperature on leaf production and vegetative growth of Avena fatua. Ann Bot 64, 469-479

Schaal B (1980) Reproductive capacity and seed size in Lupinus texensis. Am J Bot 67, 703-709

Shanmuganathan V, Benjamin LR (1992) The influence of sowing depth and seed size on seedling emergence time and relative growth rate in spring cabbage (Brassica oleracea var capitata L). Ann Bot 69, 273-276

Sunderland N, Brown R (1976) Development during vegetative growth in the apical region of the shoot of Lupinus albus. Ann Bot 40, 199-212

Toon PG, Haines RJ, Dieters MJ (1991) Relationship between seed weight, germination time and seedling height growth in Pinus caribaea Morelet var hondurensis Barret and Golfari. Seed Sci Technol 19, 397-402

Waldia RS, Chandgi RMA, Chabra BS, Sher Singh Verma (1990) Association of some seedling characters with seed mass in lentil. Lens Newslett 17, $12-14$

Weiner J, Mallory EB, Kennedy C (1990) Growth and variability in crowded and uncrowded populations of dwarf marigolds (Tagetes patula). Ann Bot 65, 513-524

Wenzel WG (1990) Influence of seed weight on seedling growth rate in grain sorghum. Angewandte Bot $64,13-17$

Wulff RD (1986) Seed size variation in Desmodium paniculatum. II. Effects on seedling growth and physiological performance. J Ecol 74, 99-114 